\title{
Identification of Variables and their Influence on the Human Resources Planning in the Territorial Level
}

\author{
Rodobaldo Martínez-Vivar (iD, Alexander Sánchez-Rodríguez (iD), \\ Reyner Pérez-Campdesuñer (iD, Gelmar García-Vidal \\ Equinoctial Technological University of Ecuador (Ecuador)
}

rodobaldo.martinez@ute.edu.ec, alexander.sanchez@ute.edu.ec, reyner.perez@ute.edu.ec, gelmar.garcia@ute.edu.ec

Received: February 2016

Accepted: May 2016

\section{Abstract:}

Purpose: The purpose of this paper lies in the use of experimental way through empirical tools for identification of the set of variables and their interrelationships and influences on the human resources planning at the territorial level.

Design/methodology/approach: The methodology used to verify the existence of the variables that affect the planning of human resources at the territorial level consists of two phases: a qualitative study of the variables that influence the planning of human resources, where the explicit variables are measured and/or implied raised in the literature analyzing the main contributions and limitations expressed by each of the authors consulted. Then it proceeds to confirmatory phase (quantitative) to prove the existence of the dimensions of the planning of human resources in the territorial level through the use of multivariate statistics through the combination of expert analysis and techniques of factorial grouping.

Findings: Identification is achieved by using empirical methods, variables that affect human resources planning at the territorial level, as well as their grouping essential dimensions, while the description of a theoretical model that integrates the dimensions is made essential and relationships that affect human resource planning at the regional level, which is characterized by the existence of systemic and prospective nature. 
Originality/value: The literature shows two streams that address a wide range of approaches to human resources planning. The first is oriented from the business object and the second part of the management in highlighting a limited territorial level to address this latest theoretical development, an element that has contributed to the fragmented treatment of human resources planning and management in general at this level. The originality of this paper is part of the creation and adaptation, on a scientific basis of a theoretical model developed from the conceptual contribution of this process at the territorial level where the key variables that affect this process are integrated, highlighting the systemic approach prospective based on solid scientific foundations.

Keywords: human resources, human resources planning, strategic, systemic, territory

\section{Introduction}

The human resources management (HRM), is of significant importance in contemporary administration, demonstrating its evolution in multiple approaches that contribute to the foundations of the current concepts.

This feature is characterized by significant interrelationships processes dating from the beginning of the Industrial Revolution (Marrero-Fornaris, 2002; Sánchez-Rodríguez, 2005; Cuesta-Santos, 2010, Martínez-Vivar, Marrero-Fornaris \& Pérez-Campdesuñer, 2013; Ramesh, Kumar-Ghosh, Prakash, Sharma, Rajaram, Kar et al., 2015; Lajos, Tedesco, Passini, Dias, Nomura, Rehder et al., 2015), be managed activities relating to recruitment, absenteeism control, maintenance of discipline and payroll. From the last five years of the last century a style oriented renewed consider man as an end result of this process, assessing with greater emphasis on knowledge as an asset of successful organizations and processes that ensure approaches are highlighted.

This development is focused essentially on the organizational level, showing a limited range in the consulted authors addressing the issue from the land. In isolation quantitative planning process is approached through the methods of balance of labor resources and rewards (incentives) (Resolución 132, 2004; Armstrong-Stassen, 2009). Similarly, the training process and the qualitative to the quantitative integration analysis is included (Law, Wong \& Wang, 2004; Pérez-Izquierdo, 2010; Cribeiro-Díaz, 2011); observed a purely qualitative nature of planning where the training process addresses only, without considering the treatment of the subject at the territorial level (Resolución 132, 2004). This is evidence of shortcomings, as the systemic nature of HRM is not guaranteed. 
Authors who are consulted, although considered in their generality environment analysis, fail to relate processes at this level HRM state, sectional interests and their relationship and/or connection with training centers. These aspects limit the realization of the strategic contributions, also not conceive business elements defining activity levels; demonstrating both a systemic breakdown as strategic and not conducive to watching HRM as a process of necessary interest in the territorial level.

New styles of HRM confident in the method involving them to the man as the final outcome of the process Revolution (Morales-Cartaya, 2009; Cuesta-Santos, 2010) make it possible to raise the HRM as fundamental to human, organizational and territorial development from an economic, political and social as a natural edge in settings where this is exercised base.

This allows to raise human resources planning (HRP) (Cribeiro-Díaz, 2011; Boffill Vega, 2009) as the initial variable whereby the remaining processes of the HRM will encourage affirmed the above elements, from its impact on the optimization of labor productivity based on continuous and progressive innovation.

In this way the HRP requires the realization of the latest trends of HRM, among which stand out prospective and systemic nature, as well as to facilitate control prospecting in the decision making (Cuesta-Santos, 2010). These elements, integrated and adapted to the particularities of each context, permit empowering results that determine the identification, strengthening and use of endogenous capacities and exogenous opportunities. This taxed consistently, permanent and harmonious aware individual, organizational and territorial development.

The result of this theoretical observation generates, inter alia, the phenomenon of movement of people (Nagla, 2011; Paromita, 2009). Among the authors consulted two streams for analysis are evident, one that focuses its theory from the territorial level (Cuesta-Santos, 2010; Torres-Cala, 2011; Cribeiro-Díaz, 2011) and the other from the organizational level. The first approaches the subject from the population by migration from analysis of both human resources (HR) and general population, and the second from the labor fluctuation experienced by HR in organizations in certain periods of time.

This analysis allows to raise roots groups of variables that cause such behavior, linked to economic, political, social and natural aspects; which although specifically manifested in each stream, they are not isolated for analysis at the territorial level. These elements have been addressed piecemeal by the authors consulted, mainly in territorial, which limits a comprehensive analysis of the subject, where a negative impact can be seen in the development at this level, expressed as:

- Inconsistencies between production and/or service structures and skill levels, generating some specialties for one over-qualification for the performance of other charges and disqualification 
expressed in HR deficits and/or skills for developing charges. This is motivated primarily by internal sectoral migration branches with lower training requirements but with higher levels of remuneration.

- Low correspondence between work location and level of qualification achieved.

- Voluntary unemployment HR high level of qualification.

- External migration to locations better development and/or better living conditions, among other factors affecting the continuity of supply of specialties to meet the challenges of territorial development.

This synthesis of arguments determines the need of this paper and bases their objective to identify key variables and their interrelationships and consistent grouping dimensions that affect HRP in the territorial level.

\section{Analysis of Approaches to Human Resources Planning}

The literature shows two streams that address a wide variety of approaches to HRP. The first object oriented from the business, highlighting authors like (Marsán-Castellanos, 1987; Maynard, 1996; and Niebel, 1997), which primarily direct their contributions to the scientific organization of work; contributing to the foundation for further studies on the HRP in particular and HRM in general, as well as others among them (Harper \& Lynch, 1992; Cuesta-Santos, 2010; de Miguel-Guzmán, 2001; Marrero-Fornaris, 2002; Armstrong-Stassen, 2009; Morales-Cartaya, 2009; Cuesta-Santos, 2010), although not in general use the term HR, if specifically oriented to planning generally the human factor and management at the organizational level. The second part stream management in the territorial level as gathering authors (Rodríguez-Fariñas, 1990; García-Espalter \& García-Espalter, 2005; Resolución 132 MES, 2004; Paromita, 2009; Gaete-Quezada, 2009; Bonardo, 2009; Pocovi, 2009; Becerra \& Toledo, 2010; Torres-Cala, 2011; Cribeiro-Díaz, 2011; Nagla, 2011) observed a limited development of this theory regarding addressed before current element that has contributed to the fragmented treatment of HRP and general management at this level; arguments each of which were analyzed and drew their main contributions and limitations, from a hierarchical cluster analysis using the SPSS version 16.0.

The dendrogram analysis result with a cut at level 15, shows the presence of five major groups: the first, by authors such as integrated (Harper \& Lynch, 1992; Cuesta-Santos, 2010), those with its proposals in the last decade of the last century, emphasizing their contributions in a more methodological and philosophical than technical approach, without achieve sufficient depth in how to act, while the depth of the treated variables varies among them, limiting their contributions to organizational level. 
In the second group they are: (Marsán-Castellanos, 1987; Maynard, 1996; Niebel, 1997). Those who show a markedly quantitative, offering a wide range of techniques for the development of this process, obviating the qualitative elements and the need to plan the remaining processes of HRM, with an operating standing vision that limits the analysis from the strategic and control, lack of adaptability for interpretation from the land.

The third group focuses on the research conducted in the early years of this century. Grouping authors as (Cuesta-Santos, 2001; Marrero-Fornaris, 2002; Sánchez-Rodríguez, 2005; Armstrong-Stassen, 2009; Morales-Cartaya, 2009) which delve into the planning from the qualitative, in trying to establish methods the determination of labor competencies needed workers, but do not develop, at least explicitly, the ways of integration of this element of the HRP with the remaining processes of HRM, showing a limited scope of the analysis to the level organizational.

The fourth group includes authors (de Miguel-Guzmán, 2001; Cuesta-Santos, 2010); proposals incorporating the integration of quantitative and qualitative planning of staffing needs and planning of the remaining processes of HRM, highlighting the systemic and strategic approach, achieving harmoniously integrate these elements are achieved also incorporate strategic control tools for HRM in general and in particular as HRP is the scorecard, highlighting de Miguel-Guzmán its strong service orientation. Generally consulted proposals are part of the current organizational those with low adaptability for use at national level.

The fifth group is associated with the current territorial where the authors are concentrated (Rodríguez-Fariñas, 1990, García-Espalter \& García-Espalter, 2005; Resolución 132 MES, 2004; Paromita, 2009; Gaete-Quezada, 2009; Bonardo, 2009; Pocovi, 2009; Becerra \& Toledo, 2010; TorresCala, 2011; Cribeiro-Díaz, 2011; Nagla, 2011), highlighting a technical and methodological treatment with limited philosophical tendencies in proposals of Rodríguez-Fariñas, Pocovi, Gaete and Paromita, limited to a strategic focus on the contributions of Jung Sook, García-Espalter, Nagla, Bonardo and Becerra, no trace of general systemic approach to HRM and HRP in particular, addressing irregular and very limited integration between qualitative and quantitative elements manner, failing to incorporate analysis tools, strategic control, limiting their contributions to the demographic assessment aimed to forecast the availability of both people and jobs from a fragmented view to observe the mobility of HR as an inherent and closely related to organizational and management level in the territorial level phenomenon. Generally, this group stands authors who consult addressing theory HRP at territorial level, they do not achieve sufficient depth while the criteria vary among them to address HRM processes that occur at this level as well such proposals are seen as limited in action, while the depth of the treated variables ranges between. 
Treaties approaches differ (strengths and weaknesses), which are the cause of the subgroups formed in the dendrogram and in the opinion of this author, there are shortcomings that limit the efficiency and effectiveness of HRP in the territorial level. These may be characterized as:

- Weaknesses in the integration of qualitative and quantitative planning at the territorial level.

- Limited proactive in HRP at the territorial level and their control.

- Limited to address the systemic nature PRH at the territorial level, as determined by the non-integration of HRM processes that occur at this level as objects of HRP.

- Limited adaptability of the methodologies and techniques developed at the organizational level for implementation in the territorial level.

- Limited integration of HRM in general and particularly HRP the remaining processes of territory management.

- Limited and fragmented observation variables generated mobility of HR in any level discussed.

As elements integrated solutions as part of the procedure presented in the next section.

\section{Methods}

The HRP at the territorial level is a complex multidimensional construct, within which to consider structural, procedural and outcome aspects. This network of relationships makes it difficult to verify the degree of influence elements in particular, what justifies the use of expert judgment to identify the degree of participation of the variables that affect the HRP at this level.

The procedure used to check for the essential variables consists of two phases: a qualitative investigation of the variables influencing the HRP and the confirmatory phase (quantitative) of the existence of dimensions, by using multivariate statistics.

\subsection{Phase 1: Qualitative Research}

This phase was conducted in two stages. First HRP variables explicit and/or implicit raised in the literature, where two streams are distinguished to address HRP were assessed. One of them is oriented from the organizational order, which include: (de Miguel-Guzmán, 2001; Morales-Cartaya, 2009; Cuesta-Santos, 2010); which do not use the term in its generality HR, although having a specific orientation to the general planning of human resources and management at the 
organizational level way. The second trend is represented by: The other stream is represented by: (Bonardo, 2009; Torres-Cala, 2011; Pérez-Izquierdo, 2010; Armstrong-Stassen, 2009; Cribeiro-Díaz, 2011), who develop their management from the territorial level, distinguishing a limited evolution of the theory about the power before addressed. This element has contributed to the fragmented treatment of HRP and general management at this level. Arguments of each analyzed and its main contributions and limitations extracted. Subsequently a list of variables extracted from the analysis was designed, which is mainly linked with the prospective nature of planning, its systemic performance, control and environmental influences.

With this list of variables, a questionnaire which was applied to a panel of experts consisting of 15 specialists HRM, that in 100\% of cases have upper level and vast experience in their profession was designed. Academic teachers are consultants in the field and have scientific status of $\mathrm{PhD}$ of Technical Sciences or Economics and have a national and international origin. The selection panel was made for a coefficient greater than 0.7 skills. The results allowed to consider the views expressed valid.

The list of variables surveyed, including three new variables not conceived in the original questionnaire, associated with maternity or parental leave, the performance of military service and promotions charges was obtained. Finally explicit remained 41 variables that influence somehow in the HRP on the territorial level.

\subsection{Phase 2: Confirmatory (Quantitative)}

We proceeded to the ordering of the variables obtained by level of importance. For it was surveyed a total of 400 experts, 354 valid questionnaires processed and discarded $1 \%$ of the total applied. The representativeness of the valid sample was as follows: 30 academics $(18 \mathrm{PhD}$ of Technical Sciences or Economics and 12 Masters), 19 government officials, 94 heads of institutions, 94 HT managers and HT specialists 117 (nationals). Of all proposals variables 35 were selected as shown in Table 1, which were referred to in $80 \%$ or more of respondents cases being followed criteria of Noda, González and Pérez (2005), who use similar selection criteria for such purposes.

In the design of the instruments it was achieved check the internal consistency and reliability of the scale used, obtained through a pilot test a Cronbach's Alpha coefficient greater than 0.70; which it is regarded as acceptable for the purposes of the study. With the information obtained data arrays that were created then processed, using factor analysis by the principal component method. 


\begin{tabular}{|c|c|c|c|}
\hline $\begin{array}{l}\text { Theoretically identified variables } \\
\text { that affect the HRP }\end{array}$ & $\%$ & $\begin{array}{l}\text { Theoretically identified variables } \\
\text { that affect the HRP }\end{array}$ & $\%$ \\
\hline Priority of the state for the profession & 96 & Applicability of competences & 100 \\
\hline Forming ability of training centers & 90 & Promotion possibilities & 84 \\
\hline Social recognition of the profession & 100 & Life conditions & 100 \\
\hline Social recognition of the sector & 100 & Occupational safety and health process & 96 \\
\hline Benefits being of the profession & 100 & Recruitment process & 96 \\
\hline Benefits to be the sector & 100 & Potential assessment process & 6 \\
\hline Priority of the state to the sector & 96 & Inventory charges and staff process & 96 \\
\hline Distance from training centers & 90 & Audit process & 48 \\
\hline Training costs & 100 & Selection process & 96 \\
\hline Quality of training centers & 100 & Incentives process & 100 \\
\hline Efficiency of the training process & 96 & Training process & 100 \\
\hline Competences of the cloisters of the training centers & 100 & Performance appraisal process & 24 \\
\hline Retirement age & 100 & Work systems process & 18 \\
\hline Moving to another territory & 84 & Existence of the strategic plan & 100 \\
\hline Military service & 12 & Quality control of the strategic plan & 100 \\
\hline Transfer to another center & 84 & Control of the strategic plan & 100 \\
\hline Maternity leave & 30 & Quality of strategic plan & 100 \\
\hline Deaths & 84 & Changes in activity levels & 100 \\
\hline Retirement due to illness & 90 & New investments & 100 \\
\hline Economic conditions & 100 & Technological changes & 100 \\
\hline Training opportunities & 84 & & \\
\hline
\end{tabular}

Table 1. Results of applying the experts applied for the ordering of the variables that affect the territorial level HRP questionnaire

\section{Results}

According to the results shown in Table 2 about the validity and reliability of factor analysis, it was considered that the technique used was valid to explain the behavior of the variables included in the study. In the first four components can explain the $75.85 \%$ of the total variance, highly positive. The first axis explains $22.37 \%$ of the total variance, the second axis $43.53 \%$, the third axis $60.23 \%$ and $75.85 \%$ the fourth. These results confirm that the structure of the axes on the considered variables can explain the phenomenon in a high degree. 


\section{Reliability analysis:}

Cronbach's Alpha coefficient: 0,893

\section{Analysis of validity:}

Kaiser-Meyer-Olkin coefficient: 0,885

Barttett Sphericity test: 15504,807

Significance: 0

\begin{tabular}{|l|c|c|c|c|}
\hline Study variables & Axis I & Axis II & Axis III & Axis IV \\
\hline Eigenvalues & 7.8 & 7.4 & 5,8 & 5,4 \\
\hline Contribution to the total variance & $22.37 \%$ & $21.16 \%$ & $16.69 \%$ & $15.62 \%$ \\
\hline Cumulative percentage of variance explained & $22.37 \%$ & $43.53 \%$ & $60.23 \%$ & $75.85 \%$ \\
\hline
\end{tabular}

\section{Correlation between variables and axes}

\section{Variables}

Component

2

\begin{tabular}{|c|c|c|c|}
\hline .051 & -.008 & -.028 & .742 \\
\hline-.003 & -.011 & -.027 & .647 \\
\hline-.053 & -.037 & -.050 & .944 \\
\hline-.070 & -.040 & -.056 & .957 \\
\hline-.050 & -.051 & -.066 & .955 \\
\hline-.017 & -.056 & -.057 & .945 \\
\hline-.019 & -.049 & -.037 & .917 \\
\hline .031 & .104 & .983 & -.051 \\
\hline .032 & .098 & .979 & -.054 \\
\hline .034 & .097 & .987 & -.054 \\
\hline .024 & .100 & .987 & -.059 \\
\hline .008 & .101 & .981 & -.062 \\
\hline .010 & .100 & .961 & -.058 \\
\hline .618 & -.022 & .026 & -.007 \\
\hline .449 & .095 & .031 & -.036 \\
\hline .892 & .050 & .072 & .007 \\
\hline .875 & .054 & .076 & . \\
\hline .918 & .045 & .032 & -.016 \\
\hline .955 & .013 & .024 & -.017 \\
\hline .837 & .024 & -.030 & .006 \\
\hline .846 & -.014 & -.014 & -.043 \\
\hline .781 & .030 & .014 & -.025 \\
\hline .810 & .003 & .012 & -.028 \\
\hline .787 & .027 & -.056 & .025 \\
\hline .769 & .019 & -.028 & -.026 \\
\hline .039 & .975 & .085 & -.034 \\
\hline .021 & .718 & .056 & -.070 \\
\hline .095 & .735 & .030 & -.059 \\
\hline-.020 & .681 & .055 & .042 \\
\hline .055 & .958 & .086 & -.041 \\
\hline .031 & .923 & .075 & -.056 \\
\hline .054 & .843 & .076 & -.002 \\
\hline .065 & .900 & .059 & -.023 \\
\hline .001 & .869 & .091 & -.070 \\
\hline .003 & .894 & .049 & .023 \\
\hline
\end{tabular}

d. Quality of strategic control

e. Changes in activity levels

f. Technological changes

g. New investments

h. Occupational safety and health process

i. Personal inventory process

j. Recruitment process

k. Selection process

1. Training process

m. Incentives process

n. Priority of the state to the profession

o. Priority of the state to the sector

p. Industry profits

q. Benefits of the profession

r. Social recognition of the sector

s. Social recognition of the profession

t. Trainability

u. Training costs

v. Distance training centers

w. Cloisters skills

x. Efficiency of the training process

y. Quality of training centers

z. Retirement age

aa. Retirement due to illness

ab. Death

ac. Transfer to another center

ad. Transfer to another territory

ae. Economic conditions

af. Life conditions

ag. Promotion possibilities

ah. Applicability skills

ai. Training possibilities

Table 2. Results of correspondence analysis for HRP at national level 
Figure 1 shows the factorial plane formed by the axes I and II, where each distinct grouping represented dimension illustrated. They stand variables associated with influences which lead to territorial policies that affect the social, sectoral and territorial recognition of specialties, and in turn determine the expectations of the candidates and their balance in the first. Also variables associated with training centers that contribute to the quality of that statement groups. The second dimension includes variables that affect the mobility of HR, both inter-territorial and extraterritorial, grouped in variables associated with working life and HR both economic and social elements of self-fulfillment and HR influencing behavior patterns emigration and/or immigration.

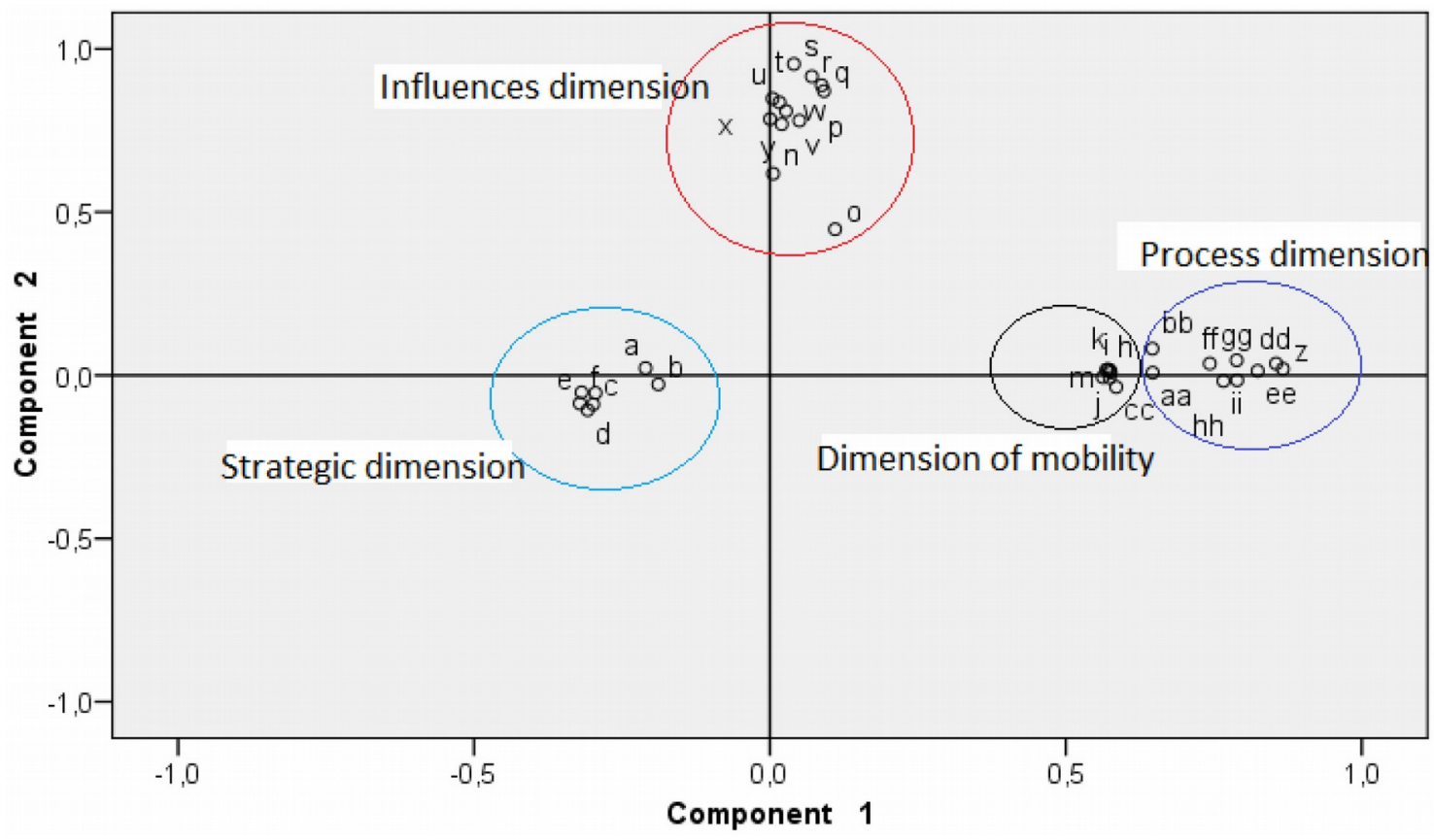

Figure 1. Factorial plane determined by the axes I and II of the principal component analysis

The third grouping HRM processes that occur at local level, responsible for ensuring the equilibrium state of the HR. The fourth dimension is linked to strategic variables that determine and/or influence the strategic management of the territory and as part of this, organizations that compose it.

To check the dimensions and variables selected describe a reliable character to construct forms the territorial HRP, the Cronbach's Alpha coefficient for each particular variable dimension was calculated; for all of them took meritorious than 0.80 reliability coefficients values. Then we proceeded to remove the items in succession to check whether improved reliability and noted that in any case the increase experienced by the Cronbach's Alpha coefficient justifies the elimination of the variable or dimension; so it is concluded that the HRP at the territorial level is acceptably collected by the 35 key variables extracted 
from factor analysis. Grouping the variables in the four dimensions has also considered sufficient coefficients $(0.936,0.995,0.947$ and 0.958 respectively).

Figure 2 shows the conceptual model for HRP at territorial level, which is derived from the experimental study conducted.

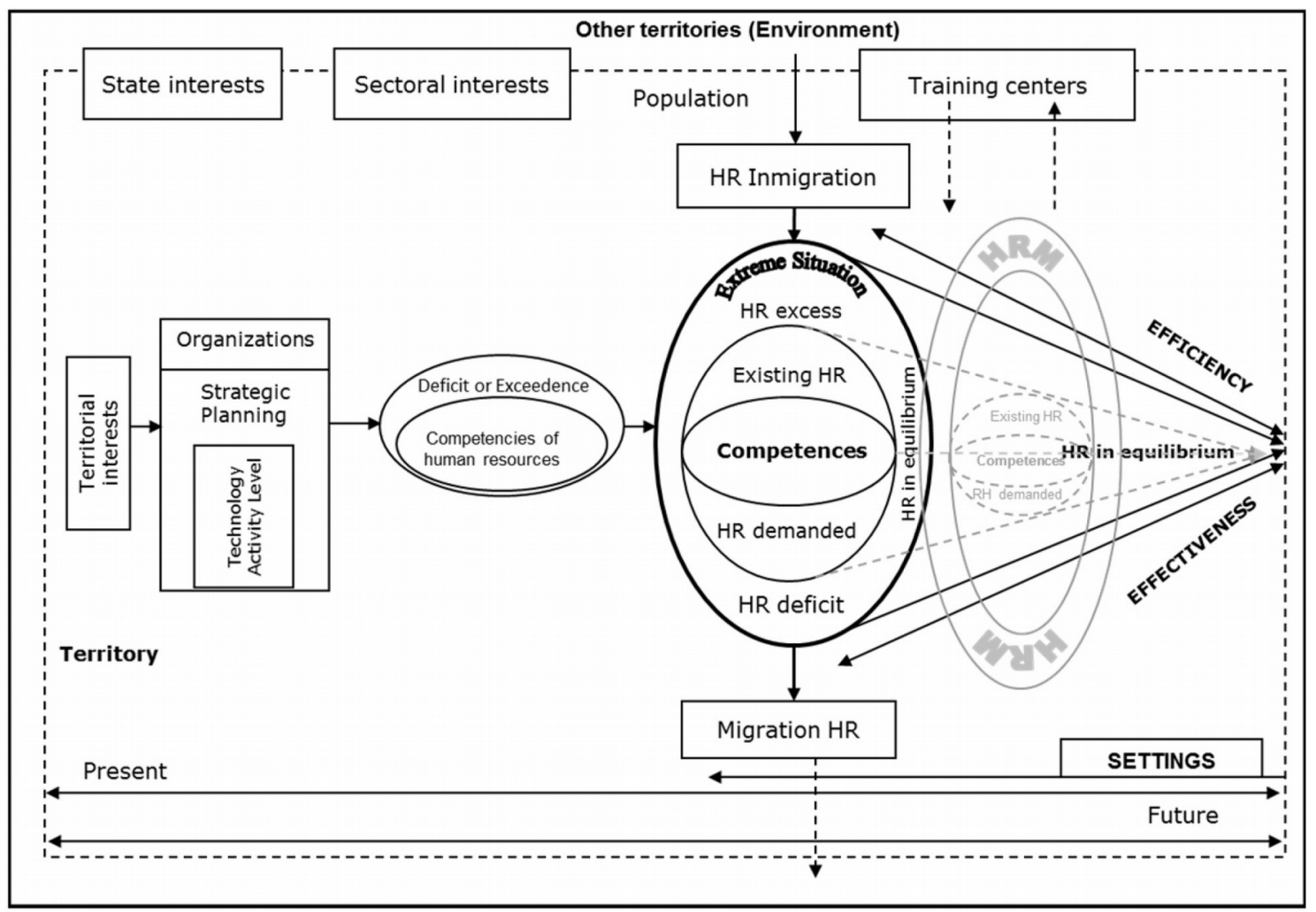

Figure 2. Conceptual model for the planning of human resources at territorial level

The four essential dimensions that support this model, ensuring that systemic and prospective nature of the HRP on the territorial level materializes, after considering the integration and interaction of groups of variables associated with both external and internal elements of the territory and consideration HRM processes that occur at this level, to ensure the equilibrium state of the HR. At the same time emphasis on the prospective nature, evidenced in considering the various time horizons in which planning and adjustments, in addition to the bonding process as part of the prospective development of the territory, developed from inclusion becomes both state and sectoral interests and territorial relations as elements of the environment.

The four dimensions resulting from the above analysis, but for your organization and identification numbers assigned to them, they do not necessarily respond to the warrant for his explanation as a system. 
The model is based on recognizing the fundamental process inputs in study obtained, both internal and external factors associated territory of the essential dimensions and strategic influences that contribute to the formation of the prospective plan of territorial development which affect the interests sectoral state and that may be part of their territory or not. For this vision groups HR requirements are both qualitative and quantitative demand, those derived from prospective activity levels that are to be assumed by the organizations of the territory. As part of the internal factors linked to the dimension of mobility, where existing HR are concentrated in the territory, represented the fluctuation from these experience, both between organizations and outside this territory is included, and the conditions that generate this phenomenon.

From these inputs, the HRP process at territorial level assumes an interactive character of certifying the correspondence between the activity levels projected by organizations and HR demands that support it, resulting to the time horizon that is planned a type of extreme situation showing equilibrium states, deficits and/or excess HR rate is required at national level.

The appearance of these states implies planning processes manifested in the dimension III, associated with HRM at territorial level, which contribute to attenuate the states of deficits and/or excess to favor the kind of balance that is required HR this level both in quantity and in quality.

Through the process of charges and staff inventory have achieved the population registry and demographic details of the territory, which show the population historical performance and trend of development as a source of assurance for the process of territorial development. Together we can evaluate the behavior of the economically active population and the availability of trained HR and in training, and to describe the requirements of inventory charges at territory.

The recruitment process is determined by the types of statements that inventory requirements and staff positions manifest territory and is based on actions that are directed from training centers backed by the organizations demanding of HR. Their deployment is aimed at promoting the social recognition of the profession, from a sectoral recognition of it, including state action for prioritization.

For this process to take place, two situations caused by the state of inventory requirements and staff positions territory are necessary. First, if the state is in excess of HR, recruitment will be directed to ensure the selection of suitable sources for specialties that are expressed in deficits. Second, if the state is in deficit, recruitment must be based on the development of training plans, the valuation of qualities and quantities of HR required and subject to its design, by the variables that define the cycle efficiency deformation. The result in both cases should lead to induction, which is the process that ensures the use of HR located and/or formed according to the program executed. 
The selection process involved from the recruitment needs of the territory and deployed according to the interests of the state, from the action of training centers (entrance examinations, aptitude and/or attitude test, free access) or the body in charge of managing HR at the territorial level. This contributes to the guarantees of quality and/or quantity for the completion of both training plans as the charges fail to cover.

As part of this systemic process acts the process of incentives, which take part in the realization of the state prioritization of those professions that become apparent deficits, with the aim of promoting social and sectoral approach and the consequent recognition and maintenance of status balance. This state demand for sustainability and continuous process improvement for stability, and the process should ensure conditions of life and work in the territory to ensure that state.

The process will contribute to the safety and health system typified by professions of policies, strategies and/or actions that the territorial level are understood from state action, to help raise the quality of life of both the RH and population in general. It also contributes to the identification of generic skills as this issue is concerned, that should be included as part of the training plans.

These actions are aimed at achieving efficiency and effectiveness of HRP process in particular and in general HRM at the territorial level, as part of the development process at this level. These should be monitored through a system of indicators, to prospectively from its application in the present conditions, measure the likely behavior of states of equilibrium and act accordingly on the processes that they say. All with the aim of ensuring compliance with the planned and optimization and good performance of financial, material and human resources; responsible for the development of this process.

The dialectical relationship so far addressed, helps to explain graphically the HRP at the territorial level as a process that integrates four essential dimensions with a high level of statistical explanation, demonstrating its complex character. At the same time, it favors systematic endeavor to sequence designed to project future scenarios based on a set of entries associated with elements of both internal and external environment, which materialize in the territorial interests and activities are assumed by the organizations for the development of their strategic plans. Timely and rational manner, transformations are guaranteed to ensure the necessary amount of HR and the required skills that are manifested, as the state of balance and means that guarantee, expressed HRM processes identified in this level and its systemic nature, with the aim of obtaining as outputs tribute to the efficiency and effectiveness of HRP in particular and generally HRM at the territorial level. 


\section{Discussion}

The explicit model for HRP at territorial level, is the result of extensive consultation both theoretical and practical. It bases its results from the use of multivariate statistics, demonstrating the existence of four essential dimensions composed of variables that show action on the HRP at this level. The presence of the systemic nature of this process based on the demonstrated relationships between variables and/or the resulting dimensions and the prospective character of each dimension own states, showing an appropriate level of both validity and reliability of the instruments used in the analyzes performed. Specifically it contributes to:

- The identification, using empirical methods, variables that affect the HRP at territorial level as well as their grouping essential dimensions.

- The graphics and theoretical description of a model that integrates the essential dimensions that affect the HRP at national level.

- The rationale described in the model of the existence of systemic and prospective nature of the HRP at the territorial level.

- These elements have been addressed piecemeal by the consulted authors addressing the issue from the territorial and not contribute to the efficiency and effectiveness of this process.

\section{Conclusions}

The review of the literature consulted on the subject, reveals two streams to address the HRP: one associated with organizational management, which has experienced extensive development evolution of philosophies, techniques and methods for inserting nuanced character strategic and systemic HRP and HRM in general as well as considering the trends of contemporary HRM; and other manifested from the territorial level, which does not contribute from its conception and application integration trends HRP expressed from the organizational, highlighting its limitations strategic concept, its systemic approach, considering the scope of the functions of HRM and the lack of a strategic approach control.

The HRP at the territorial level is a highly complex construct, which sets interacting variables grouped into four essential dimensions. These manifest from their interaction on the HRP action at this level, highlighting the systemic nature of this process, from the connectivity between the dimensions and the prospective nature as an intrinsic part of each dimension.

The instruments used in the principal component analysis, demonstrate an acceptable level both validity and reliability, enabling the statistical explanation of multidimensional construct associated with the HRP 
at national level. It contributes to the identification and assessment of relevant statistical key variables that affect each dimension composing the multidimensional construct of the HRP at national level.

The conceptual model is provided, it is based on experimental demonstrations by the way, which helps to orient graphically the essential dimensions that make up the HRP at the territorial level is achieved and support their interrelationships, favoring the character systemic and strategic HRP at this level.

\section{References}

Armstrong-Stassen, M. (2009). 'The effect of relational age on older Canadian employees' perceptions of human resource practices and sense of worth to their organization. The International Journal of Human Resource Management. 20(8), 1753-1759. ISSN 0958-5192 print/ISSN 1466-4399. http://dx.doi.org/10.1080/09585190903087156

Becerra, L., \& Toledo, M. (2010). El ordenamiento territorial del turismo a partir de un enfoque prospectivo. Turismo y Desarrollo Local, 3(8), 16-29.

Boffill-Vega, S. (2009). Modelo de gestión para contribuir al desarrollo local, basado en el conocimiento y la innovación en Cuba. Ingeniería Industrial, 30(2), 2-5. ISSN: 1815-5936.

Bonardo, D. (2009). Los manos en el ámbito municipal y el desarrollo local. Pilquen. Sección Ciencias Sociales. año XI, número 1.

Cribeiro-Díaz, Y. (2011). Contribución de la fuerza de trabajo calificada al crecimiento económico en Cuba. Principales determinantes. Tesis en opción al grado científico de doctora en ciencias económicas. Universidad de la Habana. Cuba.

Cuesta-Santos, A. (2001). Gestión por competencias. La Habana: Editorial Academia.

Cuesta-Santos, A. (2010). Tecnología de Gestión de Recursos Humanos. 4ta. Ed. La Habana: Editorial Academia/Editorial Félix Varela. ISBN 978-959-07-1340-8 OC.

de Miguel-Guzmán, M (2001). Tecnología para la planeación estratégica de los recursos humanos en entidades turística. Revista Ingeniería Industrial, 22(2), 29-34. ISSN: 1815-5936.

Gaete-Quezada, R. (2009). Diagnóstico de la función de gestión de recursos humanos de los servicios públicos de la ciudad de Antofagasta en Chile desde la perspectiva de la responsabilidad social corporativa interna. Documentos aportes administración pública y gestión estatal, (13), 39-71. http://dx.doi.org/10.14409/da.v1i13.1248 
García-Espalter, R., \& García-Espalter, J. (2005). Aplicación de un enfoque prospectivo para la proyección de la fuerza de trabajo calificada en el perfil de las ciencias económicas y empresariales. Inédito, 7-76. Available at: http://www.eumed.net/

Harper, \& Lynch (1992). Manuales de recursos humanos (1 al 12). Gaceta de Negocios. Madrid.

Lajos, G.J., Tedesco, R.P., Passini, R., Dias, T.Z., Nomura, M.L., Rehder, P.M. et al. (2015). Methodological Issues on Planning and Running the Brazilian Multicenter Study on Preterm Birth. The Scientific World Journal, 2015. http://dx.doi.org/10.1155/2015/719104

Law, K., Wong, C., \& Wang, K. (2004). An empirical test of the model on managing the localization of human resources in the People's Republic of China. International Journal of Human Resource Management. 75(4), 635-648. http://dx.doi.org/10.1080/0958519042000192870

Marrero-Fornaris, C. (2002). Propuesta para la gestión de la formación de los recursos humanos en instalaciones hoteleras. Ingeniería Industrial, 23(2), 14-16. ISSN: 1815-5936.

Marsán-Castellanos, J. (1987). La organización del trabajo. Tomo I. Editorial ISPJAE. La Habana.

Martínez-Vivar, R., Marrero-Fornaris, C.E., \& Pérez-Campdesuñer, R. (2013). Planificación de recursos humanos de un territorio turístico: El caso de Holguín-Cuba. Estudios y perspectivas en turismo, 22(4), 583-606.

Maynard, H. (1996). Manual de ingeniería y Organización industrial. La Habana: Editorial ENPES.

Morales-Cartaya, A. (2009). Capital Humano. Hacia un sistema de gestión en la empresa cubana. La Habana: Editora Política. ISBN 978-959-01-0855-6.

Nagla, M. (2011). Migrant Labour and Leisure: An Analysis. South Asian journal of Tourism and Heritage, 4(1). 117-124. ISSN No 0974-5432.

Niebel, B. (1997). Métodos, Tiempos y Movimientos. México: Editorial Alfaomega.

Noda, M., González, J., \& Pérez, R. (2005). Dimensiones esenciales de la satisfacción de clientes en hoteles. Investigacion y Marketing, 88, 31-36. ISSN: 1131-6144.

Paromita, G. (2009). A critique of the unorganized workers' social security act. Economic and Political weekly,. 44(11), 26-34. ISSN 0012-9976.

Pérez-Izquierdo, V. (2010). Transformaciones de la fuerza de trabajo en Cuba ante la crisis global. 
Pocovi, G. (2009). Gestión y desarrollo de recursos humanos: Clave para la transformación y la modernización de la administración pública. El caso de la Provincia de Santa Fe. Documentos aportes administración pública y gestión estatal, 12, 101-104.

Ramesh, B.M., Kumar-Ghosh, A., Prakash, V., Sharma, M., Rajaram, S., Kar, A. et al. (2015). Facility mapping: A tool for effective planning for MNCH services. Annals of Global Health, 81(1), 81-82. http://dx.doi.org/10.1016/j.aogh.2015.02.692

Resolución 132 (2004). Resolución 132 del 2004 del Ministerio de Educación Superior en Cuba. Normas y procedimientos para la gestión del postgrado. (Accesed: April 2010).

Rodríguez-Fariñas, R (1990). Planificación territorial en la economía socialista. La Habana: Editorial CENIC.

Sánchez-Rodríguez, A. (2005). Como gestionar los recursos humanos sobre la base de competencias laborales. Ingeniería Industrial. 26(2), 4-10.

Torres-Cala, Y. (2011). Proyección de la demanda de fuerza de trabajo calificada al año 2020, para el Municipio de Mantua, Provincia Pinar del Rio. Observatorio de la Economía Latinoamericana, 157.

Journal of Industrial Engineering and Management, 2016 (www.jiem.org)

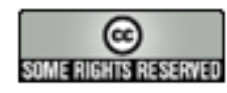

Article's contents are provided on an Attribution-Non Commercial 3.0 Creative commons license. Readers are allowed to copy, distribute and communicate article's contents, provided the author's and Journal of Industrial Engineering and Management's names are included. It must not be used for commercial purposes. To see the complete license contents, please visit http://creativecommons.org/licenses/by-nc/3.0/. 